\title{
Peace Consensus of The Political Identity In Mamasa District
}

\author{
Rahmad M. Arsyad ${ }^{1,}$, Endang Sari ${ }^{2}$ \\ \{rahmad.arsyad@binus.ac.id'1,Alridh13@gmail.com²
}

\begin{abstract}
Department of Communication Science, Faculty of Economics and Communication, Bina Nusantara University, Jakarta, Indonesia ${ }^{1}$, Department of Political Science, Faculty of Social and Political Sciences at Hasanuddin University, Makassar, South Sulawesi, Indonesia ${ }^{2}$
\end{abstract}

\begin{abstract}
Mamasa Regency, West Sulawesi is a regency with majority population of Protestant Christians with percentage of $75.36 \%$. Whereas Muslims only have population of religious identity of $12.86 \%$. However, in the two periods of direct regional head elections from 2013 to 2018 and 2018-2023, this regency is led by the Regent Ramlan Badawi who is a Muslim. Morover, in the second period, Ramlan Badawi joined the election of the regional head by becoming a sole candidate and won with a score of $61.22 \%$. The political phenomenon in Mamasa Regency is an anomaly from the tensions and identity politics conflicts that currently occur in many regional elections in Indonesia. By using the Ralf Dahrendorf approach of two faces of society, namely 'conflict and consensus', this research reveals two main conclusions that why the identity politics, particularly religious-based are not occured in Mamasa Regency is that by maintaining the memory of trauma of regional expansion conflicts as lessons and efforts to present wisdom of the past as peace consensus as well as the ability of political strategy of actor Ramlan Badawi.
\end{abstract}

Keywords: Identity Politics, Ramlan Badawi, Ralf Dahrendorf; Conflict, Consensus

\section{Introduction}

Mamasa Regency, Province of West Sulawesi has a population of 149,809 people. The majority of population in this district is Protestant Christians with a percentage of $75.36 \%$, while Muslims are $12.86 \%$ or 23.078 people compared to the Christian population of 104,480 people. For two periods or ten years, Regent Ramlan Badawi, who is a Muslim, has led the district with 17 sub- districts. Moreover, in the second election of 2018, "Ramlan Badawi became the sole candidate and won the election with a percentage of $61.24 \%$ or chosen by 48,618 voters [5]." Political phenomena in Mamasa Regency with the victory of minority group over the majority is a phenomenon that are contrary to the heat of political conflict in the regional elections arena in Indonesia, such as the Jakarta Regional Election, also the problem of white supremacy, when Donald Trump won the US election that shook the world.

Ralf Dahrendorf, a political philosopher as well as a German sociologist (1986) [3] explains that conflict always arise due to imbalances between community relations, economic class differences, authority, as well as the balance of the majority and minority. Theoretically, the 
conditions should emerge in the arena of regional head elections like Mamasa Regency if it is seen based on the composition of the majority and minority religious identities.

However, why this phenomenon become an anomaly in the political stage of the Mamasa regency election, where Ramlan Badawi, a Muslim with minority status, sucessfully selected to be the winner for two periods of the Mamasa regency election of 2013-2018 and he is selected again to be the regent of the area for period of 2018-2023 with status as a sole candidate.

The argument of Ralf Dahrendorf [3] about society has two faces, "conflict and consensus" is appropriate to revealed in seeing the anomalies that occurred in the Regency of Mamasa. Primarily in terms of analyzing what kind of peaceful consensus presented by the Mamasa community, in which the issue of supremacy of the majority and minority religious identity that usually emerge in the electoral arena as well as contributed to conflicts and segregation between groups precisely not occur in the Regency of Mamasa for two regional head elections.

Based on the background and theoretical view, this research became important at least to explain two main things. Firstly, why the political conflict of religious identity is not found in the election of regional head in Mamasa Regency, West Sulawesi. In fact, Christians as a group with the supremacy of the majority religious identity (domination) in relation to the position of Muslims as a minority group (submission). Secondly, how did Ramlan Badawi's strategy in establishing a consensus on the Mamasa Regency voters to accept himself as a representation of minority actors so that finally reelected as the regional leader for two periods.

\section{Research Method}

The method used in this research is qualitative method. This method approaches social phenomena that specifically reveal the reasons people behave and act as they do [4]. Meanwhile, the stages of the method and technique steps of data collection are as follows:

First: Research library. In this stage, the researchers conduct a literature study related to the object of research including a number of research results on the behavior of Mamasa Regency voters in 2013 and 2018 as theoretical references to formulate research designs concerning conflict theory and consensus, and also other sources of literature.

Second: Field interview. The total informants interviewed were 4 people, with two primary informants namely Stenly Gideon and Kemal Antasari, as well as two secondary Indonesia Development Engineering Consultant (IDE-C) researchers Akbar Najamuddin and Fransiska) this research was conducted for 3 months from June to August. The researcher conducts interview to find information through field sources related to the object of research. By selecting two categories of sources, namely primary sources which are those who have knowledge of the political situation and political culture of Mamasa Regency and those who have information about actor Ramlan Badawi. While secondary sources are a number of researchers and those who are concerned with observing the political development of Mamasa Regency and West Sulawesi Province.

Third: Data reduction. In the third stage, the researcher selects the main points of the field findings, organizes the data from the literature study and research interviews to make conclusions. The analytical methods used by researchers in this study are qualitative methods, interviews, and participatory observation as instruments for collecting data and narrative analysis.

Fourth: The fourth stage is the final stage in which the researcher tries to draw conclusions about the focus of the study as a research conclusion 


\section{Result and Discussion}

\subsection{Memories of Region Expansion Conflict and the Peace Consensus in Mamasa}

"From 2002 to 2005, we were too tired to be in a conflict situation, the Mamasa community were divided into two groups, namely the pro-expansion group and those who rejected". The statement from Stenly Gideon, a youth leader, church activist, as well as descendants of the Mamasa Regency traditional leader seems to open up a long dark memory of the formation of Mamasa Regency which is divided through Law Number 11 of 2002 concerning the Establishment of Mamasa Regency which is still under the authority of South Sulawesi Province at that time.

From the beginning, the plans for the expansion of Mamasa Regency as an independent district separated from Polewali District were rejected by several groups. The report of the National Legal Development Agency [8] states that the division of Mamasa Regency separated from Polewali Regency received the loudest rejection from three communities including Aralle District, Tabulahang District and Mambi District (ATM).

The rejection contributed to a long riot that occurred from 2002 to 2005 and resulted to the death of people. Hundreds of houses were damaged and the of death of people between pro and contra group could not be avoided, it even forced thousands of Mamasa residents out of Mamasa Regency.

Community groups who reject the regional expansion which is mostly Muslim, choose to leave the Mamasa regency to join the Muslim community in Polewali City and several Muslim villages outside the Mamasa regency, while the supporting group, which is mainly Christian majority, decided to stay in Mamasa Regency. Segregation between pros and cons groups is not just a matter of regional expansion. However, it is more related to the issue of population balance of religious identity. The majority of people in the Aralle, Tabulahang and Mambi (ATM) areas are Muslim, different from the religion of people in Mamasa in 14 other sub-districts that are predominantly Christian.

Ralf Dahrendorf's [3] view which explains that 'conflict arises because of an imbalance of authority in the community is true if it is seen from the background of the conflict in the division of Mamasa Regency in the past. Fear of becoming a minority group (submission) and no longer being a majority (domination) overshadows the minds of Muslim groups in the three districts. In contrast to the situation when status of Mamasa as Polewali-Mamasa district, Muslim community in the Aralle, Tabulahang and Mambi Districts, which are part of the majority religious identity in Polewali-Mamasa District, that means more authority than when it became an independent district.

The shadow of fear as a minority group and the loss of identity authority prompted a rejection that contradicted the interests of the groups that supported the division and eventually resulted in a long conflict for almost three years. The memory of this past conflict, according to Stenly Gideon, is a dark historical part that has caused prolonged conflict trauma for the Mamasa people until now. The feeling of trauma still remains and forms a collective memory of the bad consequences of latent identity conflict.

After a long riot as a result of the division of regions which led to a conflict of religious identity, the government, the police, and a number of community leaders began to make a joint agreement. Particularly, after the riots on October 2004 with three points of agreement, as follows: First, promise to live in harmony and peace as a family in the custom of Pitu Ulunna Salu. Second, promising to forget all problems and start building a family like the ancestors of 
Pitu Ulunna Salu. Third, if someone starts an act that damages the brotherhood of the Pitu Ulunna Salu region, it will be dealt firmly in accordance with the religion and advice of the ancestors of manurungan Botto, while the provocateurs who triggered the conflict will be dealt with violently by firing on the spot [8].

Through this collective agreement, the entrance to a peaceful consensus for the Mamasa Regency conflict began. Particularly in terms of combining law enforcement and cultural values which has been the customary consensus that lives in the Mamasa community as part of the kinship ties of the Pitu Ulunna Salu Mamasa community. In line with the conclusions of Maurice Halbwach [2] regarding the use of collective memory that reconciliation to the past also provides moral lessons that guide and show the way for the present community through past conflicts, the people of Mamasa Regency actually return to their cultural wisdom.

The wisdom that comes from the memory of conflict that remains a feeling of trauma in the past becomes an asset for the Mamasa community in building their social institutions not to be involved in conflict. Various peace consensus based on Mamasa cultural values are presented as the foundation of social life in Mamasa Regency. Stenly Gideon explained, in addition to building a spirit of togetherness within the Pitu Ulunna Salu family frame, other cultural values that are reappointed and became a peaceful consensus for the Mamasa community over identity conflicts are the values contained in Sumpa To Pao, a traditional agreement around 200 years old. Sumpa To Pao contains 7 items of agreement between traditional leaders in Mamasa Regency. The contents of Sumpa To Pao explicitly regulate consensus and alliance with the Mamasa region and the values of togetherness that must be believed and held firmly by the Mamasa community at any time.

To 'Pao' in Mamasa language means mango tree. Until now, the mango tree which is a witness to the traditional agreement still exists in the capital city of Mamasa Regency. Stenly Gideon explained that the spirit of Sumpa To Pao is rooted in the philosophy of the Mamasa people "" Mesa kada dipotuo pantan kada dipomate "which means" One Word We Live But If Each Is Different We Will Die "this philosophy is one of the cultural values of the era in Mamasa who revealed that unity is the key to the future of Mamasa Regency. Similar to the traditional advice, "Ole lako ole diayai sitayuk sikamase sirande maya maya" which means mutual respect, appreciation, love and lift each other up "according to Stenly Gideon is a spirit-value for the people of Mamasa today in addressing differences including differences in government and political leadership.

Stenly Gideon also explained that a peaceful consensus to separate political and governmental affairs and religion is basically also agreed upon since Mamasa Regency began to become an independent district separated from Polewali. The inter-tribal agreement that we call the agreement in 'lantang kada nene' in Mambi sub-district.

The agreement, contains two important points, including the Mamasa community believe that political and governance issues are separate from religion or ethnic identity. Second, the government of Mamasa Regency which will be formed must put attention to the principle of representation among religious identities. If the Regent is Muslim, the Deputy Regent must be Non-Muslim and vice versa. Therefore, Stenly Gideon believes that if consensus and principles based on past wisdom are well maintained, conflicts in Mamasa Regency will not occur again, including conflicts due to differences in religious or ethnic identity in politics and government.

\subsection{Actor Strategy: Power Sharing, Convention, Elite Negotiations}

In addition to the trauma factors of past conflicts, the peaceful consensus through referencing various wisdoms such as the spirit of Pitu Ulunna Salu, Sumpa To Pao and also lantang kada nene', another thing that needs to be considered behind the presence of a peaceful 
consensus of political identity in religious identity in the Mamasa Regency is a political actor of Ramlan Badawi.

Referring to Ralf Dahrendorf's [3] view regarding authority and position, the position of actor Ramlan Badawi as a political actor becomes important. Mainly, how Ramlan Badawi carrying out his strategy in minimizing conflicts of religious identity in Mamasa Regency.

The researcher found three peculiarities of Ramlan Badawi in reducing conflict and creating a joint consensus among residents of Mamasa Regency. These three things, also include an explanation of how Ramlan Badawi retained the authority of his authority and could win the election battle in the second period to reach $61.22 \%$.

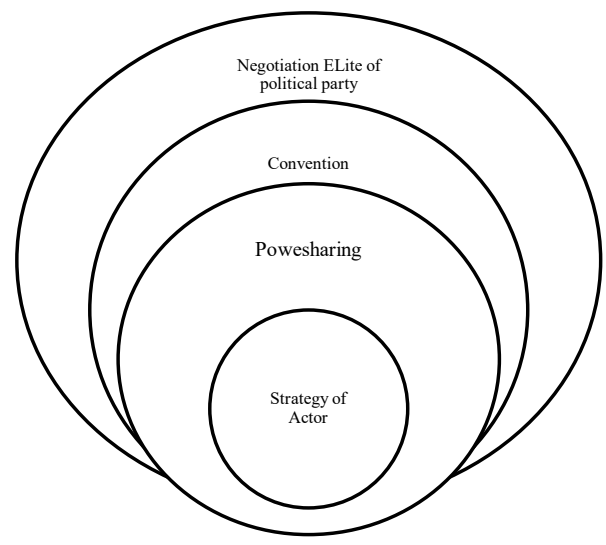

Fig. 1. Actor's Political Model in constructing a Consensus of Identity (researchers' findings) about strategy of political consensus by Ramlan Badawi

First, Power Sharing (Sharing power). According to Ralf Dahrendorf [3], power or authority contains two elements, namely the ruler (person in position of authority) and the person controlled. Ralf Dahrendorf [3] then divided the three types of groups. First, the quasi group (quasi group). Second, the interest group (manifest) and third, the Conflict group

The quasi groups are position holders with similar interests but are not yet aware of their existence and this group is also included in the second type of group, that is interest groups and because of this interest, there is a third group namely social conflict group. The three groups described by Ralf Dahrendorf [3] which became the basis of the legitimacy of power authority in reality, are groups that always get attention by Ramlan Badawi in the form of power sharing, that have proven as an effective way in minimizing political conflicts that lead to the emergence of political conflicts based on religious identities that occur in several head elections area.

Kemal Antasari, one of the leaders of the youth organization of the Nasdem Party from West Sulawesi, who is also well acquainted with the Regent Ramlan Badawi, explained that the practice of sharing power carried out by Ramlan Badawi in all components of the group can be seen from several indications "starting from the determination of the deputy district head that still refers to the representation of Christian religious identity, bureaucratic leadership led by the majority religious identity, and distribution of financing allocations for the activities of religious leaders such as priests, village priests and traditional leaders are routinely given by Ramlan Badawi ".

Practically, the sharing power carried out by Ramlan Badawi, especially in determining the deputy district head who must refer to the balance of identity was also recorded in a survey 
conducted by the Indonesia Development Engineering Consultant (IDE-C) who conducted a survey before the Mamasa District Election in December (2017) [10] :

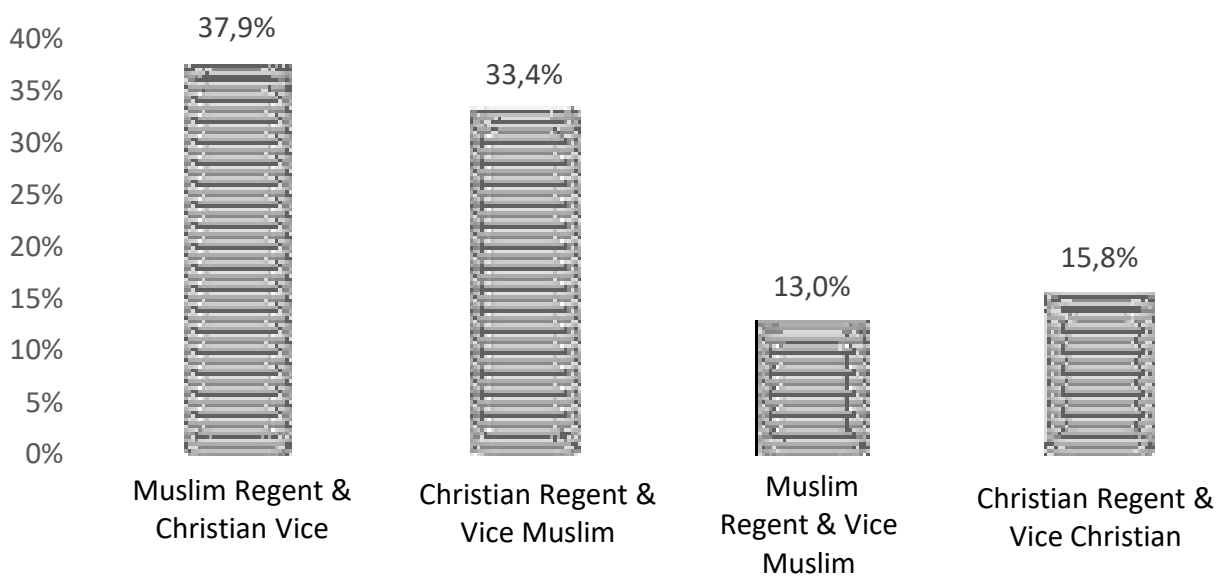

Fig. 2. Survey of voter's behavior of Mamasa Regency

The results of this survey revealed that basically (37.9\%) Mamasa voters expected the composition of representation of religious identity to be considered. Ramlan Badawi's popularity as a Muslim regent candidate for the second period is high compared to figures from Christian representatives.

If it is accumulated, $71.3 \%$ of Mamasa Regency voters at the time wanted a combination of two faith-based identity compositions to be the reason for choosing candidates for regents, both the composition of Muslim regents and Christian representatives and vice versa.

In the bureaucracy, this sharing of power can also be seen from Mamasa offices and agencies, which are mostly from Christian identity. Similar to the position of regional authority at the subdistrict level, out of 17 sub-districts, only three sub-districts are led by people with an Islamic background, including Mambi, Aralle and Tabulahan Districts, where the three districts have a majority Muslim population.

Kemal Antasari believes that Ramlan Badawi, who previously had a bureaucratic background (ASN), understood that in addition to the official political infrastructure of political power such as political parties, in the context of Mamasa, political networks is also built through representation in the bureaucracy, therefore, by practicing sharing power in the bureaucracy Ramlan Badawi is actually building consensus among groups by conducting the practice of sharing power.

Second, the Vice Regent's Open Convention. The high level of acceptance of Ramlan Badawi, who has a background in Islamic identity as the regent of Mamasa Regency which is predominantly Christian, is also influenced by Ramlan Badawi's ability to conduct political outreach with an open convention model for the election of vice-regent.

Kemal Antasari said that in two periods, Ramlan Badawi conducted an open convention campaign by inviting all prospective deputies to carry out the campaign together and directly in front of voters, then asking the public about the person that is compatible to be deputy regent candidate to accompany Ramlan Badawi. When paired with Victor Paotonan in the first period (2013), the consideration of Victor's figure as a church figure, politician, and also having a large 
kinship relationship in Mamasa Regency when conducting open conventions finally became the main reason of Ramlan Badawi in choosing Victor as his partner.

Whereas in the second period (2018), Ramlan Badawi held open conventions routinely in every socialization that was conducted before the determination of the pair of candidates. The names of groups with Christian identity backgrounds such as David Bamba Layuk (head of the Hanura Party), Bongalangi (former deputy regent), Benyamin YD (bureaucracy / former regional secretary), and Martinus Tiranda (chairman of the Kebangkitan Bangsa Party), are always mentioned in every socialization conducted by Ramlan Badawi.

After holding open conventions in almost all regions in Mamasa Regency, Ramlan Badawi decided to pair up with Martinus Tiranda who is a politician, a former vice chairman of the DPRD of Mamasa and a figure of Sinode Mamasa of Toraja Church. The decision is the right choice, because in the end, Ramlan-Martinus successfully won with a score of $61.22 \%$ against the empty box. The habit of holding open conventions to the public is an important modality possessed by Ramlan Badawi in establishing interest negotiations among the elite quasi groups, interest groups, and conflict groups in Mamasa Regency which led Ramlan Badawi to become the regent of two periods without conflict and sharp political segregation.

Third, Conflict and Negotiation of Political Party Elites. "It's better for me to bleed in Jakarta than to fight in front of the people," the statement from Kemal Antasari following Ramlan Badawi's words illustrates how Ramlan Badawi's point of view regarding the regional elections. Ramlan Badawi prefers to channel political conflicts at the elite level and avoids the intersection of political conflicts directly at the voter level. Through political party negotiations to get full support without opponents, Ramlan Badawi managed to escape from broader political segregation.

The efforts of Ramlan Badawi is successful. It can be seen in the 2018 elections in which Ramlan Badawi locked all existing political parties and became the sole candidate to compete with empty box. The ability to negotiate in locking political party support as a prerequisite for nominating a regional head made Ramlan Badawi easily elected as a sole candidate in the arena of Mamasa regency political contestation in the second period. In line with preventing the emergence of conflicts of religious identity that spread at the community level due to division during local elections. It becomes part of the consensus strategy undertaken by Ramlan Badawi in winning political contestation in Mamasa Regency which ultimately proceeded peacefully without conflict and political segregation, like other regional heads in Indonesia.

\section{Conclusion}

The conclusion of this research reveals that a peaceful consensus on the politics of religious identity occurred in the Mamasa Regency election established by two things. First, by efforts to preserve the trauma of conflict memory during regional expansion that becomes a lesson to the people of Mamasa not to repeat past conflicts based on religious identity. It also presents the political culture and wisdom of the past in Mamasa Regency such as the spirit of Pitu Ulunna Salu, Sumpa To Pao, the agreement of lantang kada nene', as well as various other wisdoms from the Mamasa indigenous people, to build a peaceful consensus and avoid conflicts of religious identity politics. Second, the ability of actor Ramlan Badawi in power sharing for quasi political, bureaucratic and religious groups. Also political stereotyping with an open convention model that still considering the principle of representation of Muslim-Christian identity and also 
the ability of Ramlan Badawi to carry out conflict canalization through political party negotiations to carry a sole candidate to prevent direct political segregation in the public arena.

\section{References}

[1] Abduh, Syuhada .: Kebijakan Pemerintah Pasca Rekonsiliasi di Daerah Kerusuhan: Kasus Kerusuhan di Maluku Utara (dalam Jurna 1 Harmon i Vol III, no. 12) Badan Pusat Penelitian dan Pengembangan Agama, Jakarta (2004)

[2] Coser, Lewis A. (ed.).: Maurice Halbwachs on Collective Memory (Chicago and London:The University of Chicago Press) (1992)

[3] Dahrendorf, Ralf.: Konflik dan Konflik Dalam masyarakat Industri (Jakarta :Rajawali Pers) (1986)

[4] Hancock, B., Ockleford, E., and Windridge, K.: An Introduction to Qualitative Research, The NIHR RDS for The East Midlans, Nottingham (2009)

[5] Indonesia Development Engineering Consultant. Studi Perilaku Pemilih Kabupaten Mamasa (2018)

[6] Komisi Pemilihan Umum, Kab, Mamasa. Hasil Pemilu Pemilihan kepala daerah mamasa (2018)

[7] Pamungkas, Cahyo.: Interaksi Sosial antar Umat Beragama Sebelum dan Sesudah Konflik (Jakarta : Masyarakat Indonesia) (2005)

[8] Ritzer, George.: Teori Sosiologi Dari Sosiologi Klasik Sampai Perkembangan Terakhir Postmodern (Yogyakarta: Pustaka Pelajar) (2012)

[9] Susan, Novri.: Peran Adat dalam Pencegahan Konflik Masyarakat Laporan Badan Pembinaan Hukum Nasional (2012)

[10] Yasil, Suradi.:Tokoh dan Kebudayaan Mandar. LAPA R Makassar, 2004 Tim BPS Polewali Mandar. Kabupaten Polewali Mamasa dalam Angka (2001) 